\title{
Fondant Candies Enriched with Antioxidants from Aronia Berries and Grape Marc
}

\author{
OCSANA OPRIS ${ }^{1}$, ILDIKO LUNG ${ }^{1, *}$, MARIA-LOREDANA SORAN ${ }^{1}$, RODICA STURZA ${ }^{2}$, \\ ALIONA GHENDOV-MOSANU ${ }^{2}$ \\ ${ }^{1}$ National Institute for Research and Development of Isotopic and Molecular Technologies, 67 - 103 Donat Str., 400293, \\ Cluj-Napoca, Romania \\ ${ }^{2}$ Faculty of Food Technology, Technical University of Moldova, 168 Stefan cel Mare Str., MD 2004, Chisinau, Republic \\ of Moldova
}

\begin{abstract}
Aronia berries and grape marc, a by-product of producing wine, are rich in antioxidants. The aim of this work was to study the effects of powders and extracts of aronia berries and grape marc addition on physicochemical quality indicators, microbiological stability in vitro, and antiradical activity of fondant candies, during storage. In order to obtain the maximum antioxidant activity of the aronia berries and grape marc extracts, the Box-Behnken experimental design was used for optimization of the extraction method using sonication technique. During 35 days of storage, the dry mass fraction of all candies obtained significantly increased, which shows that the fondant candies obtained are stable over time. An important role was played by the antioxidant capacity of the plant materials used, whose chemical composition includes a number of biologically active substances which inhibit the development of microorganisms and allow stabilization of the fondant candies.
\end{abstract}

Keywords: vegetal materials, Box-Behnken design, DPPH, fondant candies

Berries are known for the wide variety of phytochemicals content. Among the species richest in biologically active compounds is aronia berries (Aronia melanocarpa L.), originary from North America, but which has gained wide spread in the Central and Eastern area of Europe [2]. Aronia berries have high content of phenolic compounds such as: procyanidins, anthocyanins, phenolic acids and flavonoids [3]. The aronia berries extracts were studied intensively for the many important potential health effects [3-5].

Grapes (Vitis vinifera L.), one of the most commonly consumed fruits, are used in wine industry and the main byproduct of wine producing is grape marc, which consists of the stalks, skin, pulp and seeds that remain after pressing the grapes.

In general, agro-industrial wastes are difficult to manage due to their high biological oxygen demand and scientists realize about this environmental issue and are looking for solutions [6]. However, it was found that by-products can be also promising sources of bioactive phyto-chemicals which have have several benefits on human health [7].

Gayon [8] put into evidence the importance of polyphenols through numerous studies highlighting the antioxidant character of phenolic compounds. Grape marc have bioactive components with many biological activities, such as antioxidant, cardioprotective, anti-cancer, anti-inflammatory, anti-aging and antimicrobial properties [9].

Among various modern techniques used for bioactive compounds extraction, ultrasound extraction is an economic, simple, and efficient extraction technique that can help solutes more rapidly diffuse from the solid material into the solvent [10]. Because the extraction conditions are different depending on the plant material used, the optimization of the bioactive compounds extraction is essential to obtain an improved extract. The response surface methodology (RSM) is a statistical technique, which includes the method developing, modeling, improving and optimizing processes, predicting the maximum response and evaluates the effect of the variables and their interactions [11]. This method is widely used to optimize bioactive compounds extraction, because can reduce the number of experimental runs, cost, and time $[11,12]$.

The aim of this work was to study the effect of the addition of powders and extracts of aronia berries and grape marc on the physico-chemical quality indicators, microbiological stability in vitro, and antiradical activity of fondant candies, during storage up to 35 days.

The vegetal material extracts was obtained by testing several experimental conditions applying RSM, using BoxBehnken experimental design. The extracts obtained were evaluated for their free radical scavenging activity.

We hypothesized that the addition of powder and extracts of aronia berries and grape marc to fondant candies will improve their organoleptic indices, the quality indicators, increase their microbiological stability and antioxidant activity, and also will have functional properties.

*email: ildiko.lung@itim-cj.ro (I. Lung) 


\section{Experimental part \\ Materials}

Aronia berries (Aronia Melanocarpa) are purchased from the Republic of Moldova and fresh grape marc, the Merlot variety, was obtained from the primary winery of "Româneşti S.A." (Republic of Moldova). The aronia berries and grape marc were dried at $65.00 \pm 1.00^{\circ} \mathrm{C}$ to $8.00 \pm 0.25 \%$ moisture content, milled to powder $(140 \mu \mathrm{m}$ grain size $)$, and finally sieved.

( \pm )-6-Hydroxy-2,5,7,8-tetramethylchromane-2-carboxylic acid (Trolox) was purchased from Sigma-Aldrich (Steinheim, Germany), 2,2'-diphenyl-1-picrylhydrazyl (DPPH) was obtained from Alfa Aesar (Germany) and ethyl alcohol of agricultural origin ( $96 \%$ vol.) was obtained from Aro (Bucharest, Romania).

The hydromodule shows the ratio between the liquid phase and the solid phase. Thus, these extractions were performed at the following hydromodules: 4, 6, 8, 10,12, 14, 16, 18 and 20. Further, the hydromodule 18 for aronia berries and the hydromodule 12 for grape marc was used.

\section{Ultrasonic assisted extraction}

For the ultrasonic assisted extraction, a Transsonic T 310 ultrasonic bath at $35 \mathrm{kHz}$ and an installed power of $95 \mathrm{~W}$ was used. The extraction was done from powdered dry vegetable material $(1.5 \mathrm{~g})$ in a volume $(18 \mathrm{ml}$ for aronia berries and $12 \mathrm{ml}$ for grape marc) of ethyl alcohol (96\% vol.) and bidistilled water, in various ratios (Table 1). Also, various times and temperatures were tested for extraction. For the optimization of the antioxidant activity, the Box-Behnken experimental design with three variables (sonication time, temperature and ethyl alcohol : bidistilled water ratio, Table 1), obtained by Minitab 17 program was used. Thus, 15 experimental conditions were tested. The extracts obtained were filtered and stored at $4{ }^{\circ} \mathrm{C}$ until analysis were performed. All the extracts were performed in triplicate.

\section{Extraction by reflux}

A mixture of ethyl alcohol (96\% vol.) and bidistilled water was added at $1.5 \mathrm{~g}$ dry vegetal material. The obtained mixture was refluxed for various periods of time $(10 \mathrm{~min}, 35 \mathrm{~min}$ and $60 \mathrm{~min})$. The best volumetric ratio between ethyl alcohol (96\% vol.) and bidistilled water that was established for ultrasonic extraction was also used for the extraction by reflux. The extracts thus obtained were filtered and stored at $4{ }^{\circ} \mathrm{C}$ until analysis. All extracts were made in triplicate.

\section{Determination of the antioxidant capacity of the extracts}

The antioxidant capacity was evaluated following a procedure reported by Brand-Williams et al. [13] which was slightly modified. A volume of $0.01 \mathrm{ml}$ of extract was added to $3.9 \mathrm{ml}$ of DPPH radical solution $(0.0025 \mathrm{~g} / 100 \mathrm{ml}$ of methanol), and the resulting mixture was maintained for $10 \mathrm{~min}$ in darkness. After $10 \mathrm{~min}$, the absorbance of the mixture at $515 \mathrm{~nm}$ was measured versus the control sample $(0.01 \mathrm{ml}$ of extract added to $3.9 \mathrm{ml}$ of methanol). The results were calculated from the calibration curve equation and expressed in M Trolox equivalets per $100 \mathrm{~g}$ DW vegetal material (M $\mathrm{TE} / 100 \mathrm{~g} \mathrm{DW}$ ). All determinations were made in triplicate.

\section{Fondant candies preparation}

The fondant candies were prepared based on sugar, molasses, condensed milk, butter and water, with a 5.00\% vegetal powder addition having the grain size of $140 \mu \mathrm{m}$ and the moisture content of $8.00 \pm 0.25 \%$, and hydroalcoholic extract of vegetal material with a dry matter content of $18.00 \pm 1.25 \%$, in a proportion of $0.3 \%$ reported to the product mass as a natural dye, but also as a source of biologically active compounds. The control sample was prepared similarly without vegetal material addition, and the vegetal hydroalcoholic extract was replaced with alcohol $(40 \% \mathrm{v} / \mathrm{v})$. Vacuum packed samples were stored in a dry place at $18.00 \pm 1.00^{\circ} \mathrm{C}$.

\section{Fondant candies characterization}

The physico-chemical characteristics (the mass fraction of the dry matter content, fat content, water activity, $\mathrm{pH}$, and mass fraction of reducing substances) of the fondant candies obtained were determined according to the OAC method [14].

The sensory analysis of the products were performed out according to ISO 6658:2017 [15].

The microbiological analysis were performed in accordance with the Microbiological Criteria Rules for Foodstuff [17]. The total number of germs microorganisms was estimated.

\section{Determination of the antioxidant activity of the fondant candies}

The antioxidant activity of the fondant candies was measured according Brand-Williams procedure [13]. Thus, antiradical activity of the products has been determined in vitro in order to simulate gastric digestion in the presence of pepsin $\left(150 \mathrm{mg} / 100 \mathrm{~g}\right.$ of product), at $p \mathrm{H}=2.0 \pm 0.1(1.5 \mathrm{M} \mathrm{HCl})$, temperature $\left(37.0 \pm 0.1^{\circ} \mathrm{C}\right)$, under shake of $60 \mathrm{~min}^{-}$ 
${ }^{1}$ for $2 \mathrm{~h} \mathrm{[17].} \mathrm{The} \mathrm{samples} \mathrm{have} \mathrm{been} \mathrm{centrifuged} \mathrm{at} 6000 \mathrm{rpm}$ for $10 \mathrm{~min}$, after which they have been filtered and tested as well [13]. According to bibliographical estimating, the correlation degree between in vitro scientific results, made by Monsen's model and the results obtained in vivo varies between $60-70 \%$ [18]. All assays were performed in triplicate at room temperature $20 \pm 1^{\circ} \mathrm{C}$.

\section{Results and discussions}

\section{Ultrasonic assisted extraction}

The antioxidant capacity of the obtained extracts

The calibration curve was plotted using the SMAC program and the experimental data obtained by reading the absorbances corresponding to solutions of different Trolox concentrations $(0.04-1.6 \mathrm{mM})$ at the wavelength of $515 \mathrm{~nm}$. Thus, the calibration curve equation was: $y=0.3416 x+0.0458$, with a correlation coefficient of 0.9990 . Also, the detection limits $(0.02695 \mathrm{mM})$ and quantification $(0.05327 \mathrm{mM})$ of the method were also calculated with the same program.

In the case of aronia berries, the extracts obtained by sonication with experimental run no. 10 showed the highest antioxidant capacity (55 M TE / $100 \mathrm{~g}$ DW, Table 1).

In the case of grape marc extracts obtained by sonication, the experimental run no. 4 (extraction solvent ethyl alcohol $96 \%$ vol.: bidistilled water $55: 45 \mathrm{v} / \mathrm{v}$, temperature of $80^{\circ} \mathrm{C}$ and $60 \mathrm{~min}$ sonication time, Table 1) showed the best antioxidant capacity (16.74 M TE/100 g DW).

Table 1

THE ANTIOXIDANT CAPACITY (M TE / $100 \mathrm{~g}$ DW) OF THE ARONIA BERRIES AND GRAPE MARC EXTRACTS OBTAINED BY SONICATION AND TESTING THE BOX-BEHNKEN EXPERIMENTAL DESIGN WITH THREE VARIABLES

\begin{tabular}{|c|c|c|c|c|c|}
\hline & & & & Aronia berries & Grape marc \\
\hline Assay & (min) & vol.) : water (\%) & $\left({ }^{\circ} \mathrm{C}\right)$ & $\begin{array}{l}\text { Antioxidant capacity } \\
\text { (M TE / } 100 \mathrm{~g} \mathrm{DW})\end{array}$ & $\begin{array}{l}\text { Antioxidant capacity } \\
\text { (M TE / } 100 \mathrm{~g} \mathrm{DW})\end{array}$ \\
\hline 1 & 35 & $10: 90$ & 30 & $19.41 \pm 0.11$ & $11.65 \pm 0.24$ \\
\hline 2 & 60 & $55: 45$ & 30 & $43.83 \pm 0.93$ & $15.49=0.28$ \\
\hline 3 & 10 & $55: 45$ & 30 & $41.09 \pm 0.71$ & $15.98 \pm 0.65$ \\
\hline 4 & 60 & $55: 45$ & 80 & $46.39 \pm 0.85$ & $16.74=0.81$ \\
\hline 5 & 10 & $10: 90$ & 55 & $25.03 \pm 0.41$ & $13.92 \pm 1.39$ \\
\hline 6 & 60 & $10: 90$ & 55 & $30.09 \pm 0.88$ & $11.94=0.52$ \\
\hline 7 & 35 & $100: 0$ & 30 & $25.49 \pm 0.93$ & $6.63 \pm 0.56$ \\
\hline 8 & 35 & $55: 45$ & 55 & $50.04 \pm 0.35$ & $13.15=0.58$ \\
\hline 9 & 10 & $100: 0$ & 55 & $18.81 \pm 0.68$ & $6.25 \pm 0.37$ \\
\hline 10 & 10 & $55: 45$ & 80 & $55.00 \pm 0.37$ & $14.31=0.45$ \\
\hline 11 & 35 & $55: 45$ & 55 & $50.04 \pm 0.35$ & $13.15 \pm 0.58$ \\
\hline 12 & 35 & $55: 45$ & 55 & $50.04 \pm 0.35$ & $13.15 \pm 0.58$ \\
\hline 13 & 35 & $100: 0$ & 80 & $21.38 \pm 0.55$ & $7.42 \pm 0.35$ \\
\hline 14 & 60 & $100: 0$ & 55 & $21.52 \pm 1.10$ & $6.21=0.14$ \\
\hline 15 & 35 & $10: 90$ & 80 & $41.96 \pm 1.20$ & $13.94=0.44$ \\
\hline
\end{tabular}

Extraction by reflux

The antioxidant capacity of aronia berries extracts obtained by reflux was $44.00 \mathrm{M}$ TE/ $100 \mathrm{~g}$ DW for $10 \mathrm{~min}, 52.40$ $\mathrm{M}$ TE /100 g DW for $35 \mathrm{~min}$, and 54.19 M TE/ $100 \mathrm{~g}$ DW for $60 \mathrm{~min}$.

In the case of the grape marc extracts obtained by reflux, the highest antioxidant capacity (14.70 M TE / $100 \mathrm{~g}$ DW) was obtained by reflux for $60 \mathrm{~min}$. 
The antioxidant capacity of aronia berries and grape marc extracts obtained by sonication and reflux is not significantly different. Significant diferences showed the antioxidant capacities obtained between aronia berries and grape marc, the antioxidant capacity are much higher in aronia berries than in grape marc (Fig. 1).

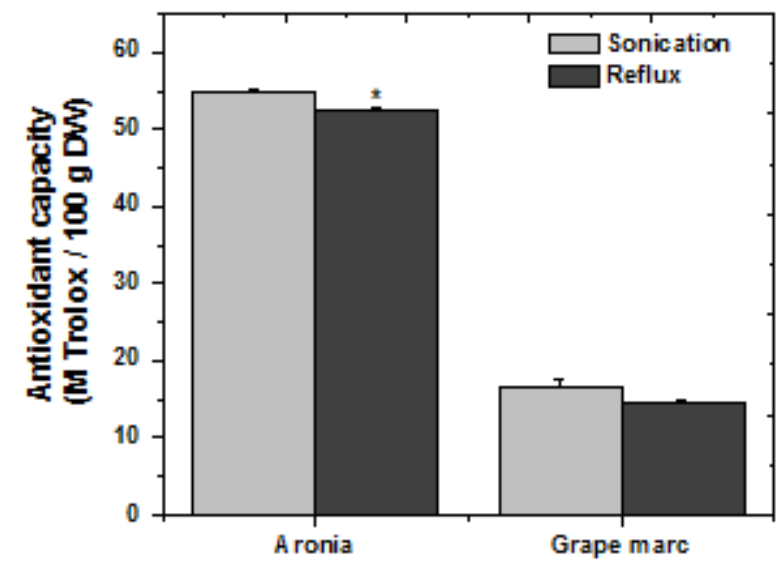

Fig. 1. The antioxidant capacity of aronia berries and grape marc extracts obtained by sonication and reflux (M TE / $100 \mathrm{~g} \mathrm{DW}$ ). The symbol above the columns "*" is for statistical differences $(p<0.05)$ between sonication and reflux techniques tested for each plant material

\section{Fondant candies}

The obtained results (Table 2) have shown that after the first day of production, the dry mass fraction increases with an average of $3 \%$ in the samples with addition of the powder and extract of the aronia berries and grape marc compared to the control sample (without vegetal material addition). This phenomenon can be explained by the fact that the added vegetal powder has a low moisture content (8\%).

Table 2

CHANGE OF PHYSICO-CHEMICAL QUALITY INDICATORS, MICROBIOLOGICAL STABILITY AND IN VITRO ANTIRADICAL ACTIVITY OF FONDANT CANDIES DURING STORAGE

\begin{tabular}{|c|c|c|c|c|c|c|c|c|c|c|c|}
\hline \multirow{2}{*}{$\begin{array}{l}\text { Fondant } \\
\text { candy }\end{array}$} & \multicolumn{2}{|c|}{$\begin{array}{c}\text { The mass fraction } \\
\text { of the dry matter, } \\
\%\end{array}$} & \multicolumn{2}{|c|}{$\mathrm{pH}$} & \multicolumn{2}{|c|}{ Water activity, $\left(a_{x}\right)$} & \multirow{2}{*}{$\begin{array}{c}\text { Fat content, } \\
\begin{array}{c}\% \\
\text { After } \\
1 \mathrm{day}\end{array}\end{array}$} & \multirow{2}{*}{$\begin{array}{c}\text { The mass fraction } \\
\text { of reducing } \\
\text { substances, \% } \\
\text { After } \\
1 \text { day }\end{array}$} & \multicolumn{2}{|c|}{$\begin{array}{c}\text { Total viable count }{ }^{\text {\% }} \\
\text { CFU/g }\end{array}$} & \multirow{2}{*}{$\begin{array}{c}\text { Antiradical } \\
\text { activity, } \\
\text { \% DPPH } \\
\text { After } \\
35 \text { days }\end{array}$} \\
\hline & $\begin{array}{l}\text { After } \\
1 \mathrm{day}\end{array}$ & $\begin{array}{l}\text { After } \\
35 \text { days }\end{array}$ & $\begin{array}{l}\text { After } \\
1 \text { day }\end{array}$ & $\begin{array}{l}\text { After } \\
35 \text { days }\end{array}$ & $\begin{array}{l}\text { After } \\
1 \mathrm{day}\end{array}$ & $\begin{array}{l}\text { After } \\
35 \text { days }\end{array}$ & & & $\begin{array}{l}\text { After } \\
1 \mathrm{day}\end{array}$ & $\begin{array}{l}\text { After } \\
35 \text { days }\end{array}$ & \\
\hline Control sample & $\begin{array}{l}86.58 \\
\pm 0.21\end{array}$ & $\begin{array}{l}90.35 \\
\pm 0.16\end{array}$ & $\begin{array}{r}7.02 \\
\pm 0.18\end{array}$ & $\begin{array}{l}6.95 \\
\pm 0.15\end{array}$ & $\begin{array}{l}0.779 \\
\pm 0.01\end{array}$ & $\begin{array}{l}0.765 \\
\pm 0.01\end{array}$ & $\begin{array}{l}0.51 \\
\pm 0.01\end{array}$ & $\begin{array}{l}12.29 \\
\pm 0.29\end{array}$ & 4 & 20 & $\begin{array}{r}4.41 \\
\pm 0.65\end{array}$ \\
\hline $\begin{array}{c}\text { With aronia powder } \\
\text { and extract }\end{array}$ & $\begin{array}{l}89.56 \\
\pm 0.11\end{array}$ & $\begin{array}{l}93.72 \\
\pm 0.21\end{array}$ & $\begin{array}{r}4.84 \\
\pm 0.11\end{array}$ & $\begin{array}{r}4.76 \\
\pm 0.09\end{array}$ & $\begin{array}{l}0.724 \\
\pm 0.01\end{array}$ & $0.705 \pm 0.01$ & $\begin{array}{l}0.42 \\
\pm 0.05\end{array}$ & $\begin{array}{l}13.75 \\
\pm 0.57\end{array}$ & 4 & 14 & $\begin{array}{l}55.43 \\
\pm 1.83\end{array}$ \\
\hline $\begin{array}{l}\text { With grape marc } \\
\text { extract and powder }\end{array}$ & $\begin{array}{l}89.55 \\
\pm 0.23\end{array}$ & $\begin{array}{l}93.58 \\
\pm 0.27\end{array}$ & $\begin{array}{r}4.35 \\
\pm 0.13\end{array}$ & $\begin{array}{l}4.20 \\
\pm 0.15\end{array}$ & $\begin{array}{l}0.713 \\
\pm 0.02\end{array}$ & $0,676 \pm 0.01$ & $\begin{array}{c}0.45 \\
\pm 0.02\end{array}$ & $\begin{array}{l}13.31 \\
\pm 0.86\end{array}$ & 0 & 1 & $\begin{array}{l}53.72 \\
\pm 1.67\end{array}$ \\
\hline
\end{tabular}

During 35 days of storage, the dry mass fraction of all samples obtained significantly increased on average by $4.0 \%$. In this way, reducing the moisture content of preserved fondant candies increases the content of dry matter, which shows that the product is stable over time [19]. It has been found that in the control sample the active acidity is 7.02 and shows the basic medium, while in the samples with addition of aronia berries the active acidity decreases 1.45 times and in the samples with grape marc decreases 1.61 times compared to the control sample. The decreasing of the active acidity can be explained by the chemical composition of the aronia berries and grape marc [2,20]. During storage (35 days) the active acidity decreases in all nonessential samples and varies between 6.95 (control sample) and 4.20 (grape marc sample).

The water activity index shows the stability or shelf life of the food. After performing the determinations, it was found that the numerical value of the water activity varies in the range $0.779-0.713$ after the first day of storage and in the range $0.765-0.676$ after the $35^{\text {th }}$ day of storage demonstrating that multiplication and survival of vegetative bacterial cells will not occur.

Concomitant, it is attested that the mass fraction of the reducing substances insignificant increases with the addition of the powder and extract the of aronia berries or grape marc in the manufacture of the fondant candies. In the case of candies with the addition of aronia berries, this indicator is $13.75 \%$, those with addition of grape marc is $13.31 \%$, and in the control sample is $12.29 \%$, but does not exceed maximum 14\% [21]. This phenomenon can be explained by the 
fact that the addition of aronia berries and grape marc contains sugars like fructose, and contribute to increase the content of reducing substances.

The fraction of the fat mass in the candies varies from $0.51 \%$ in the control sample to $0.45 \%$ in the sample with the addition of powder and extract of aronia berries, and $0.42 \%$ in the sample with powder and extract of grape marc. For samples with aronia berries and grape marc, this decrease may be explained by increasing of the total mass of the sample. Analyzing the results obtained, it can be stated that in the first day and in the $35^{\text {th }}$ day from the date of production, the physicochemical characteristics of the assortment of fondant candies obtained correspond to the admitted regulated values [21].

Regarding the multiplication of the microorganisms the main factors are the content of dried substances and water activity of the candies. Because the candies obtained have an increased content of dry matter $(90.35-93.58 \%)$ and the water activity varies between $0.676-0.765$, the Aspergillius fungi $\left(\mathrm{a}_{\mathrm{w}}\right.$ limits between $0.7-0.85$ and Saccharomyces yeasts ( $\mathrm{a}_{\mathrm{w}}$ limits between 0.62 - 0.86) can survive during storage. Also, the researches proved that the total number of germs decreases with the addition of extracts and vegetal powders, which confirms their antimicrobial activity [22]. All samples investigated on both in the first day and in the $35^{\text {th }}$ day, have admissible value of the total number of germs [16].

The appearance, taste, smell, color and consistency were evaluated organoleptically after the 5 point system. The results show that the best results were obtained in the case of the candies with the addition of hydroalcoholic extract and powder of aronia berries, followed by those with addition of extract and powder of the grape marc because combines the highest points of the organoleptic parameters and argues the use of the extracts and vegetal powders at the manufacture of fondant candies.

An important role is played by the antioxidant capacity of the plant material used, which inhibit the development of microorganisms and allow stabilization of the system $[5,20]$. In the samples with hydroalcoholic extracts, the antiradical activity is positive and has considerable values especially for the samples with addition of extract and powder from aronia berries $(55.43 \%)$ and grape marc $(53.72 \%)$, compared to the control sample $(4.41 \%)$, which presents an important argument in the favor of these products.

\section{Conclusions}

In this study, the powders and hydroalcoholic extracts of aronia berries and the grape marc were incorporated into fondant candies due to their high antioxidant capacity. These fondant candies increased the mass fraction of dry substances with an average of $3 \%$ compared to the control. The water activity varied demonstrating that multiplication and survival of vegetative bacterial cells will not occur. All the obtained fondant candies investigated, in the first day and $35^{\text {th }}$ day of storage, have the total number of germs corresponding to the admissible value. The obtained fondant candies had a positive antiradical activity (53-55\% DPPH inhibited under conditions of gastric digestion in vitro), which considerably exceeds the antioxidant activity of reference samples, $4.41 \pm 0.65 \%$ DPPH inhibited after 35 days.

The hypothesis is supported by the analysis of the organoleptic indices, the physico-chemical indicators, microbiological stability and antiradical activity of the fondant candies can be concluded that these products are competitive, have functional properties through the presence of biologically active compounds of aronia berries and grape marc and can be recommended for consumption.

Aknowledgements. This work was supported by the Project 35/BM/19.09.2016 and PN18-03 0203.

\section{References}

1. SCHEPETKIN, I.A., RAMSTEAD, A.G., KIRPOTINA, L.N., VOYICH, J.M., JUTILA, M.A., QUINN, M.T., Phytother. Res., 30, 2016, p. 1287.

2. BENVENUTI, S., PELLATI, F., MELEGARI, M., BERTELLI, D., J. Food Sci., 69, 2004, p. 164.

3. OHGAMI, K., ILIEVA, I., SHIRATORI, K., KOYAMA, Y., JIN, X.H., YOSHIDA, K., KASE, S., KITAICHI, N., SUZUKI, Y., TANAKA,

T., OHNO, S., Invest. Ophthalmol. Vis. Sci., 46, 2005, p. 275.

4. DOMAREW, C.A., HOLT, R.R., GOLDMANN-SNIKOFF, G., J. Herb. Pharmacother., 2, 2002, p. 31.

5. KULLING, E.S., RAWEL, M.H., Planta Med., 74, 2008, p. 1625.

6. LIBRÁN, C.M., MAYOR, L., GARCIA-CASTELlO, E.M., VIDAL-BROTONS, D., Agric. Sci., 4, 2013, p. 56.

7. SCHIEBER, A., STINTZING, F.C., CARLE, R., Trends Food Sci. Technol., 12, 2001, p. 401.

8. RIBEREAU-GAYON, P., Institut National de la Recherche Agronomique, Paris. 1964.

9. SAMAVARDHANA, K., SUPAWITITPATTANA, P., JITTREPOTCH, N., ROJSUNTORNKITTI, K., KONGBANGKERD, T., Int. Food Res. J., 22, 2015, p. 1169.

10. ZHANG, H.H., WANG, S., Indian J. Pharm. Sci., 78, 2016, p. 608.

11. ALBERTI, A., ZIELINSKI, A.A.F., ZARDO, D.M., DEMIATE, I.M., NOGUEIRA, A., MAFRA, L.I., Food Chem., 149, 2014, p. 151.

12. WU, Y., WANG, X., XUE, J., FAN, E., J. Food Sci., 82, 2017, p. 2726.

13. BRAND-WILLIAMS, W., CUVELIER, M.E., BERSET C., LWT-Food Sci. Technol., 28, 1995, p. 25.

14. *** Official Methods of Analysis of AOAC International, $20^{\text {th }}$ Edition (2016).

15. *** BS ISO 6658:2017. Sensory Analysis - Methodology - General guidance (2017).

16. *** Government Decision of the Republic of Moldova No. 221, 2009, (in Romanian), Official Monitor of the Republic of Moldova, 24.03.2009, no. 59-61, art. 272. 
17. MILLER, D., SCHRICKER, B., RASMUSSEN, R., VAN CAMPEN, D., Am. J. Clin. Nutr., 34, 1981, p. 2248.

18. MONSEN, E.R., J. Am. Diet. Assoc., 88, 1988, p. 786.

19. GIOVANELLI, G., PARADISO, A., J. Agric. Food Chem., 50, 2000, p. 7277.

20. JAKOBEK, L., ŠERUGA, M., MEDVIDOVIĆ-KOSANOVIĆ, M., JOVANOVIĆ, I.N., Agric. Conspec. Sci., 72, 2007 , p. 301.

21.***Government Decision of the Republic of Moldova No. 204, 2009, (in Romanian), Official Monitor of the Republic of Moldova, 20.03.2009, no. 57-58, art. 254.

22. MENDOZA, L., YAÑEZ, K., VIVANCO, M., MELO, R., COTORAS, M., Ind. Crops Prod., 43, 2013, p. 360.

Manuscript received: 20.05 .2019 